\title{
Effects of beech (Fagus sylvatica), ash (Fraxinus excelsior) and lime (Tilia spec.) on soil chemical properties in a mixed deciduous forest
}

\author{
Christina Langenbruch • Mirjam Helfrich • \\ Heinz Flessa
}

Received: 24 June 2011 /Accepted: 20 September 2011 /Published online: 8 October 2011

(C) The Author(s) 2011. This article is published with open access at Springerlink.com

\begin{abstract}
Aims We aimed to determine the influence of the distribution of different broadleaved tree species on soil chemical properties in a mature deciduous forest in Central Germany.

Methods Triangles of three neighboring trees (tree clusters) that consisted of either one or two species of European beech (Fagus sylvatica L.), European ash (Fraxinus excelsior L.) or lime (Tilia cordata Mill. or Tilia platyphyllos Scop.) were selected and analyzed for their litterfall chemistry and chemical properties of the forest floor and mineral soil $(0-10 \mathrm{~cm}$ and $10-20 \mathrm{~cm})$.

Results Base saturation, $\mathrm{pH}$-value and the stock of exchangeable $\mathrm{Mg}^{2+}(0-10 \mathrm{~cm})$ were highest under ash and lowest under beech. The proportion of
\end{abstract}

Responsible Editor: Alfonso Escudero.

C. Langenbruch $(\bowtie)$

Soil Science of Temperate and Boreal Ecosystems,

Büsgen-Institute, Georg-August-Universität Göttingen,

Büsgenweg 2,

37077 Göttingen, Germany

e-mail: Christina.Langenbruch@forst.uni-goettingen.de

M. Helfrich • H. Flessa

Institute of Agricultural Climate Research, Johann Heinrich

von Thünen-Institut, Federal Research Institute for Rural

Areas, Forestry and Fisheries,

Bundesallee 50,

38116 Braunschweig, Germany exchangeable $\mathrm{Al}^{3+}$ was smallest under ash and highest under beech. The stock of exchangeable $\mathrm{Mg}^{2+}$ and $\mathrm{Ca}^{2+}$ correlated positively with the annual input of the respective nutrient from leaf litterfall. Ash leaf litterfall contained highest amounts of $\mathrm{Mg}$ and $\mathrm{Ca}$. Beech leaf litterfall showed the highest $\mathrm{C}: \mathrm{N}$ ratio and lignin: $\mathrm{N}$ ratio. Soil $\mathrm{pH}$, stocks of organic $\mathrm{C}$, total $\mathrm{N}$ and exchangeable $\mathrm{Mg}^{2+}$ and $\mathrm{Ca}^{2+}$ correlated positively with increasing proportions of ash leaf litter to total leaf litterfall.

Conclusions Our results indicate that the abundance of ash in beech dominated forests on loess over limestone had a positive effect on soil chemical properties and reduced soil acidification. The intermixture and distribution of ash in beech-dominated stands resulted in an increase of the horizontal and vertical diversity of the soil habitat.

Keywords Broadleaved tree species · Nutrient stocks · Leaf litter $\cdot$ Soil acidification
Abbreviations
$\mathrm{BS} \%$
$\mathrm{C}_{\text {org }}$
$\mathrm{N}_{\mathrm{t}}$
CEC
$\mathrm{LL}_{\text {(tree species) }} / \mathrm{LL}_{\text {total }}$
$\mathrm{LL}_{\text {ash }} / \mathrm{LL}_{\text {total }}$ 


\section{Introduction}

Tree species affect soils through many factors, such as the rates and distribution of nutrient and water inputs, outputs and cycling (Binkley and Giardina 1998). While the relative influence of conifers, as compared to hardwoods, on soil biochemical properties has often been analyzed (Augusto et al. 2002; Berger et al. 2009a, b; Mareschal et al. 2010), research on soil chemical variations under different broadleaved species is a younger and less advanced field. The main findings of studies analyzing soil properties under broadleaved tree species are that $\mathrm{pH}$ and base saturation are lower in the topsoil under mullmoderforming species (including beech) compared to mullforming tree species (including ash and lime; Nordén 1994; Neirynck et al. 2000; Oostra et al. 2006). Further, Oostra et al. (2006) and Vesterdal et al. (2008) found out that concentrations and stocks of organic carbon $\left(\mathrm{C}_{\text {org }}\right)$ and total nitrogen $\left(\mathrm{N}_{\mathrm{t}}\right)$ in the forest floor were higher for beech than for ash and lime. (The latter was only analyzed by Vesterdal et al. 2008.) In the mineral soil it was vice versa.

Tree species influence soil chemical properties through differences in the quantity and chemistry of their leaf litterfall (Reich et al. 2005; Vesterdal et al. 2008; Guckland et al. 2009). In their review, Augusto et al. (2002) ranked tree species in the order of decreasing acidifying ability: conifers $\geq$ beech, oak and birch $\geq$ Norway maple, hornbeam, ash and lime. They described several ways by which species can acidify soils, including litter composition, deposition and root exudates. Data on the effects in mixed stands is especially scarce, and there is a need to clarify the relationships between composition of mixed stands and nutritional properties on a small spatial scale (for a review, see Rothe and Binkley 2001).

Recently, Guckland et al. (2009) conducted a field study in a highly diverse broadleaved forest in Hainich National Park in central Germany using a plot design where different diverse $50 \times 50 \mathrm{~m}$ stands were compared. They discovered significant differences in various soil properties between pure beech stands and mixed stands of mainly three (European beech (Fagus sylvatica L.), European ash (Fraxinus excelsior L.) and lime (Tilia cordata Mill. \& Tilia platyphyllos Scop.)) or six tree species (in addition hornbeam (Carpinus betulus L.), Sycamore maple (Acer pseudoplatanus L.) and
Norway maple (Acer platanoides L.)). Soil pH, base saturation and cation exchange capacity were found to rise with increasing species diversity and decreasing beech abundance. However, the clay content tended to be lower in beech stands, which could also have been an important factor influencing the above mentioned soil properties. Therefore, Guckland et al. (2009) could not fully differentiate between a possible effect of tree species mixture, a beech gradient effect or a clay content effect.

In this paper, we present the results of a study design, where the effects of European beech (Fagus sylvatica L.), European ash (Fraxinus excelsior L.) and Lime (Tilia platyphyllos Mill., Tilia cordata Scop.) on soil chemical properties and nutrient turnover were analyzed at two subsites of differing loess cover in Hainich National Park, the site where Guckland et al. (2009) conducted their research. It was designed as a follow-up to the study of Guckland et al. (2009) and aimed to answer the question they raised concerning whether they detected a beech gradient effect, and to detach clay content effects from tree species effects. In a small area of approximately $90 \times 90 \mathrm{~m}$ and $250 \times 120 \mathrm{~m}$, respectively, tree triangles ("clusters") of three beeches, limes or ashes as well as mixed clusters of two of these species were chosen. With this approach we aimed to detect possible effects of tree species and tree species mixtures on forest soil chemistry, in a fully developed forest with a high diversity in broadleaved tree species. Due to the small scale approach, variations in the clay content, the loess cover or those induced by land use history were reduced to a minimum. We hypothesized that there were differences in soil properties underneath the different cluster variants that were induced by the quality of the leaf litterfall of the cluster trees.

\section{Materials and methods}

Study site

The study was conducted in Hainich National Park, which is located in central Germany in Thuringia. With up to 14 tree species per hectare, Hainich National Park belongs to one of the largest and most diverse broadleaved forests in Central Europe. The forest has existed for over 200 years and contains mature trees aged 100 to 200 years. In 1997, this area became National Park (Mölder et al. 2006). 
Two subsites were chosen for analyses. They were located at the southeast of Hainich National Park close to a meteorological station (Meteomedia, station Weberstedt/Hainich; $\left.51^{\circ} 06^{\prime} \mathrm{N}, 10^{\circ} 31^{\prime} \mathrm{E}\right)$ near the Thiemsburg. The mean annual temperature is $7.5^{\circ} \mathrm{C}$, and the mean annual precipitation is $670 \mathrm{~mm}$. The mean elevation of the sites is $350 \mathrm{~m}$ a.s.l. The forest grows on a Luvisol developed from loess underlain by Triassic Limestone. At some places, the profile showed stagnic properties. For a detailed site description, see Mölder et al. (2006).

The two subsites differed in the thickness of loess cover. Subsite 1 ("TB 60") had a mean loess cover of $60 \mathrm{~cm}$, ranging from 48 to $77 \mathrm{~cm}$ (Table 1). The clay content $(0-20 \mathrm{~cm})$ averaged $25 \%$. Subsite 2 ("TB 100") had a mean loess cover of $100 \mathrm{~cm}$, ranging from $70 \mathrm{~cm}$ to more than $100 \mathrm{~cm}$ (Table 1). The clay content $(0-20 \mathrm{~cm})$ averaged $18 \%$. Tree species under investigation appeared to grow in a random mixture with each other and there was no large grouping of ash and lime within TB 60 and TB 100.The size of TB 60 was approximately $250 \times 120 \mathrm{~m}$ and that of TB 100 approximately $90 \times 90 \mathrm{~m}$. The distance between the centers of both subsites was around $565 \mathrm{~m}$.

\section{Selection of tree cluster areas}

The impact of three tree species, i.e. European beech (Fagus sylvatica L.), European ash (Fraxinus excelsior L.) and lime (Tilia cordata Mill. or Tilia platyphyllos Scop.), and their mixtures on soil chemical properties was analyzed. These species were chosen because they are the most dominant tree species in Hainich National Park. Furthermore, results from former studies suggest that these three species differ in their effects on soil acidification and nutrient availability (e.g. Nordén 1994; Neirynck et al. 2000; Oostra et al. 2006).

At both subsites TB 60 and TB 100, tree clusters, defined as three trees that were standing in a triangle to each other, were chosen for investigation (Fig. 1). The trees had a mean distance from the cluster centre of $3.5 \mathrm{~m}$, ranging from 2 to $5.5 \mathrm{~m}$. All cluster trees were mature, having a mean diameter at breast height (DBH) of $31 \mathrm{~cm}$ (ash), $39 \mathrm{~cm}$ (beech) and $32 \mathrm{~cm}$ (lime). The three trees of one cluster had a similar DBH. The canopy in the forest stand was closed. At each site, three or more replicates of the following six cluster variants were selected: (1) pure beech, (2) pure ash, (3)pure lime (except at TB 100, because there were not enough pure lime clusters) or mixture of (4) beech and ash, (5) beech and lime and (6) lime and ash (Table 1). The number of beech clusters was higher because beech was the most abundant tree species at both sites and it was difficult to find adequate clusters containing ash and/or lime.

Litterfall sampling and preparation for analyses

Litter collectors with a diameter of $64 \mathrm{~cm}$ were installed at the center of each cluster between the soil

Table 1 General soil physical properties and number of replicates of the cluster variants at the two study sites (TB 60 and TB 100); mean with standard deviation in brackets

\begin{tabular}{|c|c|c|c|c|c|c|c|c|}
\hline \multirow{2}{*}{$\begin{array}{l}\text { Study } \\
\text { Site }\end{array}$} & & \multirow{2}{*}{$\begin{array}{l}\text { Cluster } \\
\text { variants }\end{array}$} & \multirow{2}{*}{$\begin{array}{l}\text { Thickness of loess } \\
\text { cover }[\mathrm{cm}] \text { (min-max) }\end{array}$} & \multicolumn{2}{|c|}{ Soil texture $[\%]$ sand/silt/clay } & \multicolumn{2}{|c|}{ Bulk density $\left[\mathrm{g} \mathrm{cm}^{-3}\right]$} & \multirow{2}{*}{$\begin{array}{l}\text { Number of } \\
\text { replicates }\end{array}$} \\
\hline & & & & $0-10 \mathrm{~cm}$ & $10-20 \mathrm{~cm}$ & $0-10 \mathrm{~cm}$ & $10-20 \mathrm{~cm}$ & \\
\hline \multirow[t]{6}{*}{ TВ 60} & (1) & Beech & $58-73$ & $2 / 75 / 23(0 / 4 / 4)$ & $2 / 76 / 22(0 / 4 / 4)$ & $1.1(0.1)$ & $1.4(0.1)$ & 9 \\
\hline & (2) & Ash & $53-54$ & $2 / 68 / 30(0 / 4 / 4)$ & $2 / 67 / 31(0 / 4 / 4)$ & $1.0(0.1)$ & $1.4(0.1)$ & 3 \\
\hline & (3) & Lime & $50-65$ & $2 / 75 / 23(1 / 2 / 1)$ & $2 / 76 / 22(0 / 3 / 2)$ & $1.1(0.1)$ & $1.4(0.2)$ & 3 \\
\hline & (4) & Beech-Ash & $55-60$ & $2 / 75 / 23(0 / 2 / 2)$ & $2 / 74 / 24(0 / 1 / 1)$ & $1.2(0.1)$ & $1.5(0.1)$ & 3 \\
\hline & $(5)$ & Beech-Lime & $53-77$ & $2 / 71 / 27(0 / 6 / 6)$ & $2 / 71 / 27(0 / 5 / 5)$ & $1.1(0.1)$ & $1.4(0.0)$ & 4 \\
\hline & (6) & Ash-Lime & $48-65$ & $2 / 71 / 27(0 / 6 / 6)$ & $2 / 71 / 27(0 / 7 / 6)$ & $1.1(0.1)$ & $1.4(0.1)$ & 4 \\
\hline \multirow[t]{5}{*}{ TВ 100} & (1) & Beech & $70-98$ & $2 / 79 / 19(0 / 2 / 2)$ & $2 / 80 / 18(0 / 2 / 2)$ & $1.0(0.0)$ & $1.4(0.1)$ & 5 \\
\hline & (2) & Ash & $80-96$ & $2 / 79 / 19(0 / 2 / 3)$ & $2 / 80 / 19(0 / 3 / 3)$ & $1.0(0.1)$ & $1.3(0.1)$ & 4 \\
\hline & (4) & Beech-Ash & $79-98$ & $2 / 79 / 19(0 / 3 / 2)$ & $2 / 80 / 18(0 / 2 / 2)$ & $1.1(0.1)$ & $1.3(0.1)$ & 4 \\
\hline & (5) & Beech-Lime & $70-97$ & $2 / 80 / 18(1 / 1 / 1)$ & $2 / 80 / 18(1 / 0 / 0)$ & $1.1(0.1)$ & $1.4(0.1)$ & 4 \\
\hline & (6) & Ash-Lime & $80->100$ & $2 / 82 / 16(0 / 2 / 2)$ & $2 / 82 / 16(0 / 2 / 2)$ & $1.1(0.1)$ & $1.4(0.1)$ & 4 \\
\hline
\end{tabular}




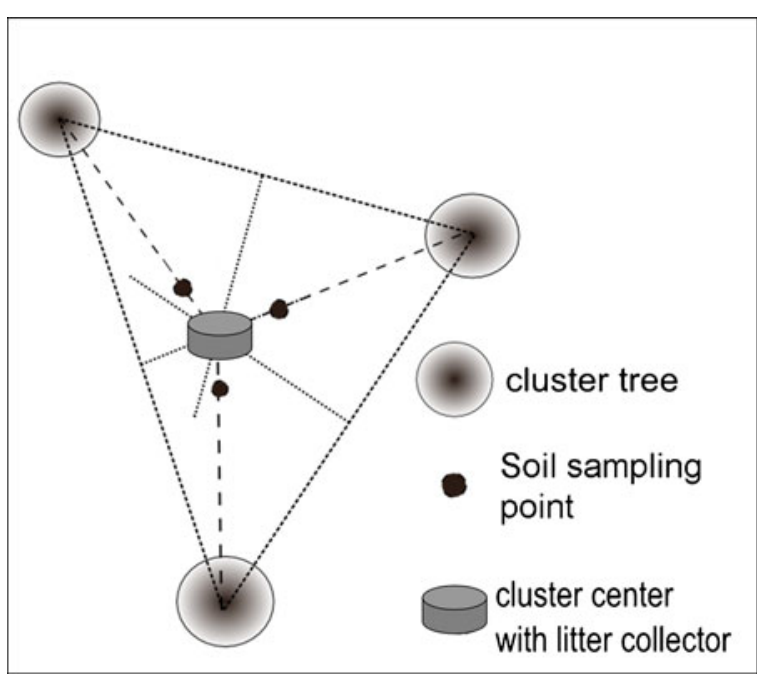

Fig. 1 Sampling design of soil and litter within a cluster area. Litter was collected from the circumcenter of the cluster while soil samples were taken approximately $50 \mathrm{~cm}$ from the circumcenter towards each cluster tree

sampling places (Fig. 1). The litterfall was sampled at four dates (Oct $1^{\text {st }} 2008$, Oct $23^{\text {rd }} 2008$, Nov $12^{\text {th }} 2008$ and March $10^{\text {th }}$ 2009). It was found in former studies that the litterfall was negligible during spring and summer (Jacob, personal communication). The litter samples were separated into fruit and leaves, and these were further divided into the cluster tree species and other dominant species. After separation, the samples were dried at $70^{\circ} \mathrm{C}$ for 4 days. The total litterfall $\left(\mathrm{Mg} \mathrm{ha}^{-1}\right)$ in 2008 was calculated for each cluster from the sum of the dry weight of all leaves and fruit from all four sampling dates.

The samples from each date from one cluster were put together as one pooled sample, however still separated into fruit, leaf and species. These samples were ground in a mixer mill (RETSCH MM2, Haan, Germany). Fruit were shredded before grinding (FRITSCH pulverisette Type 15.302, Idar-Oberstein, Germany).

Forest floor sampling and preparation for analyses

According to the morpho-functional classification of humus forms by Zanella et al. (2011), the forest floor was classified as mesomull (OL) under pure ash and pure lime clusters and as dysmull $(\mathrm{OL}+\mathrm{OF})$ under pure beech clusters. In mixed clusters the forest floor was either a mesomull or an oligomull $(\mathrm{OL}+$ discontinuous $\mathrm{OF}$ ). The forest floor was sampled from the center of each cluster in June 2008 (Fig. 1) before the litter collectors were positioned. For collection, an iron cylinder with a diameter of $27.85 \mathrm{~cm}$ was placed onto the soil surface. The forest floor in this cylinder was then collected by hand. The samples were dried at $60^{\circ} \mathrm{C}$ until the weight remained constant. The dry samples were shredded and then ground to fine material in a mixer mill (RETSCH MM2, Haan, Germany).

Soil sampling and preparation for analyses

In May 2008, three soil samples (diameter of $6.4 \mathrm{~cm}$; height of $20 \mathrm{~cm}$ ) were taken at a distance of $50 \mathrm{~cm}$ from the center of each cluster area as shown in Fig. 1.

Soil cores were cut into the depth increments of $0-10 \mathrm{~cm}$ and $10-20 \mathrm{~cm}$. Big roots were removed before weighing the fresh soil material. The soil was then dried at $40^{\circ} \mathrm{C}$, passed through a $2 \mathrm{~mm}$ sieve, and a sub-sample was ground in a planetary ball mill (RETSCH PM 4000, Haan, Germany).

\section{Laboratory analyses}

The following physical parameters of soil were determined: bulk density, gravimetric moisture (mass\%) at sampling date, and particle size distribution. Soil bulk density was calculated from the mass of dry soil and the volume of the soil core collected in field. We proved the reliability of this approach by comparing results to those produced by the standard method of determining soil bulk density (taking undisturbed soil cores from a soilprofile pit). No difference was found between the results of the two methods. Particle size distribution was determined using the sieving and pipette method (Schlichting et al. 1995).

The $\mathrm{pH}$ of the sieved mineral soil was measured in $1 \mathrm{MKCl}$-solution (10 $\mathrm{g}$ soil and $25 \mathrm{ml} \mathrm{KCl-solution).}$ Exchangeable cations were extracted from sieved soil by $1 \mathrm{MNH}_{4} \mathrm{Cl}$-solution (König 1996) and then measured by Inductively Coupled Plasma Optical Emission Spectrometry (ICP-OES, Kleve, Germany).

Effective cation exchange capacity (CEC) was calculated as the sum of exchangeable cations. Base saturation $(\mathrm{BS} \%)$ is the proportion of the sum of base cations $\left(\mathrm{Na}^{+}, \mathrm{K}^{+}, \mathrm{Ca}^{2+}\right.$ and $\left.\mathrm{Mg}^{2+}\right)$ to $\mathrm{CEC}$ in percent.

Total cation contents were analyzed after pressure digestion with concentrated nitric acid (Heinrichs and 
Loftfield 1986) in litterfall and forest floor samples. The solution was measured with the ICP-OES.

$\mathrm{C}_{\text {org }}$ and $\mathrm{N}_{\mathrm{t}}$ were measured in ground material from the mineral soil, forest floor and litterfall by an automated $\mathrm{C}$ and $\mathrm{N}$ analyzer (Heraeus Elementar Vario EL, Hanau, Germany). All samples were free of carbonates.

Lignin content of leaf litter samples from mono species clusters at TB 60 was determined using the acetylbromide method (Brinkmann et al. 2002 modified after Morrison 1972). Prior to the admixture of acetylbromide, the grounded samples were extracted using the procedure of Brinkmann et al. (2002).

\section{Statistical analyses}

Statistica 8.0 (StatSoft, Inc., 2008) was used for statistical analyses. A two-factorial analysis of covariance with "site" and "cluster variant" (excluding lime clusters) as factors and clay content as co-variable was used to detect significant differences between variants. To detect the influence of lime clusters, a simple analysis of covariance was additionally done. The Scheffé-Test was used for post-hoc comparisons in cases of significance $(p<0.05)$. When the residuals were not at least approximately normally distributed and/or the variances were not homogenous and correlated positively with the mean, a Box-Cox-transformation of the data was conducted in order to meet the above mentioned requirements. If no reasonable transformation was found, then the non-parametric Kruskal-Wallis-Anova followed by multiple comparisons (post-hoc) was used. (This test was used for base saturation and concentrations of $\mathrm{Ca}, \mathrm{Mg}$ and $\mathrm{Mn}$ in leaf litter type).

Pearson Correlations were conducted to analyze the relationship between litter nutrients $(\mathrm{Ca}, \mathrm{Mg}$ and $\mathrm{Mn})$ and soil properties. Linear multiple regression analyses were used to detect variables influencing soil chemical properties. Four theoretically possible variables were examined: (1) the proportion of beech, (2) ash or (3) lime leaf litter to total leaf litterfall and (4) the clay content.

\section{Results}

Clay content of the mineral soil of the clusters

The clay content was higher at TB 60 (22\% to $31 \%)$ than at TB $100(16 \%$ to $19 \%$; Table 1$)$. The clay content did not differ between $0-10 \mathrm{~cm}$ and $10-20 \mathrm{~cm}$ soil depths. We found no relationship between the clay content and the cluster variants. Only at TB 60 in $10-20 \mathrm{~cm}$, the clay content in beech clusters tended to be lower than in ash clusters $(p<0.1)$.

Production and composition of leaf litter

In $2008,3.6$ to $5.3 \mathrm{Mg} \mathrm{ha}^{-1}$ of litterfall was produced at our study site. The production of litterfall did not differ between the two subsites or between variants. Nevertheless, litterfall tended to be lower in pure beech clusters than in ash-lime clusters $(p<0.1)$.

The nutrient content of the leaf litterfall (calculated means over all clusters) in 2008 differed significantly between the species (Table 2). The $\mathrm{Ca}$ and $\mathrm{Mg}$ contents were lowest in beech leaf litter and the $\mathrm{Mg}$ content was highest in ash leaf litter. Beech leaf litter showed lowest $\mathrm{N}$ concentrations and the highest $\mathrm{C}: \mathrm{N}$ ratio and lignin: $\mathrm{N}$ ratio among the investigated species. Ash leaf litter showed the lowest $\mathrm{Mn}$ concentration among the investigated species. The composition of beech, ash and lime leaf litter was not influenced by the cluster species.

The variants differed in their composition of leaf litterfall in 2008. Beech leaf litter was present in all variants with $7.9 \%$ to $99.5 \%$ mass (dry matter). However, its contribution to total leaf litterfall decreased in the order pure beech clusters $>$ mixed clusters with beech present >clusters without beech present. Ash and lime leaf litter did not exceed 63.9\% (ash) and $44.4 \%$ (lime) in the respective single species clusters. In pure beech clusters almost no ash and lime leaf litter was present. The proportion of a leaf litter type to total leaf litterfall $\left(\mathrm{LL}_{\text {(tree species) }} / \mathrm{LL}_{\text {total }}\right)$ did not correlate with the clay content, except for the proportion of ash leaf litter to total leaf litterfall $\left(\mathrm{LL}_{\text {ash }} / \mathrm{LL}_{\text {total }}\right)$ at TB 60 in $10-20 \mathrm{~cm}$ depth $\left(\mathrm{R}^{2}=0.23\right.$, $p<0.05)$.

The C:N ratio in mixed litterfall collected varied significantly between pure ash clusters (34.4) and clusters with beech present (43.7 to 45.4; Table 2). Further, it varied significantly between ash-lime clusters (36.9) and pure beech clusters (45.4). The N content in litterfall of ash clusters was higher than of all clusters containing beech. Furthermore, it was higher in ash-lime than in beech clusters.

The concentration of $\mathrm{Ca}$ and $\mathrm{Mg}$ in mixed litterfall was lowest in beech clusters (16.6 and 
Table 2 Nutrient contents, C:N ratio and Lignin: $\mathrm{N}$ ratio of leaf litterfall in 2008 of different species (upper part; means from all clusters) and of mixed litterfall (leaves and fruits) of different cluster variants (lower part; mixed calculation of the contents in species litter with the proportion of the species litter to total litterfall). Mean with standard deviation in brackets. Different lower case letters indicate significant differences between the variants at a significance level of $p<0.05$ (Scheffe Test for C, $\mathrm{N}, \mathrm{C}: \mathrm{N}$ and Lignin:N; Kruskal-Wallis-Anova for $\mathrm{Ca}, \mathrm{Mg}$ and $\mathrm{Mn}$ ). There were no differences between the two subsites (TB 60, TB 100) and the mean includes results from both subsites. Lignin: $\mathrm{N}$ ratios are results from mono species clusters at TB 60

\begin{tabular}{|c|c|c|c|c|c|c|c|}
\hline Variant & $\mathrm{Ca}\left[\mathrm{mg} \mathrm{g}^{-1}\right]$ & $\operatorname{Mg}\left[\mathrm{mg} \mathrm{g}^{-1}\right]$ & $\mathrm{Mn}\left[\mathrm{mg} \mathrm{g}^{-1}\right]$ & $\mathrm{C}\left[\mathrm{mg} \mathrm{g}^{-1}\right]$ & $\mathrm{N}\left[\mathrm{mg} \mathrm{g}^{-1}\right]$ & $\mathrm{C}: \mathrm{N}$ & Lignin: $N$ \\
\hline \multicolumn{8}{|l|}{ Leaf litter type } \\
\hline Beech & $16.2 \mathrm{a}(1.4)$ & $1.5 \mathrm{a}(0.2)$ & $0.6 \mathrm{~b}(0.2)$ & $493.2 \mathrm{c}(6.3)$ & $9.9 \mathrm{a}(0.9)$ & $50.1 \mathrm{~b}(4.7)$ & $7.5 b(0.8)$ \\
\hline Ash & $24.1 \mathrm{~b}(3.3)$ & $2.7 \mathrm{c}(0.6)$ & $0.1 \mathrm{a}(0.03)$ & $471.8 \mathrm{a}(8.3)$ & $14.8 \mathrm{~b}(2.4)$ & $32.6 \mathrm{a}(4.8)$ & $4.0 \mathrm{a}(0.8)$ \\
\hline Lime & $22.5 b(2.9)$ & $2.0 \mathrm{~b}(0.4)$ & $0.5 \mathrm{~b}(0.1)$ & $486.7 \mathrm{~b}(7.9)$ & $15.3 b(1.6)$ & $32.2 \mathrm{a}(3.2)$ & 4.4a (0.6) \\
\hline \multicolumn{8}{|c|}{ Mixed litter fall of cluster variants } \\
\hline Beech & 16.6a (1.8) & $1.50 \mathrm{a}(0.19)$ & $0.61 b(0.19)$ & $493.3 \mathrm{a}(6.6)$ & $11.0 \mathrm{a}(1.3)$ & $45.4 \mathrm{c}(6.0)$ & NA \\
\hline Ash & $20.0 \mathrm{~b}(1.0)$ & $2.23 \mathrm{c}(0.29)$ & $0.28 \mathrm{a}(0.08)$ & $483.4 \mathrm{a}(3.9)$ & $14.2 \mathrm{c}(1.6)$ & $34.4 \mathrm{a}(3.6)$ & NA \\
\hline Lime & $19.3 \mathrm{ab}(1.6)$ & $1.63 \mathrm{ab}(0.06)$ & $0.55 \mathrm{ab}(0.11)$ & $491.7 \mathrm{a}(4.9)$ & $13.6 \mathrm{abc}(0.6)$ & $36.3 \mathrm{abc}(2.0)$ & NA \\
\hline Beech-Ash & $19.3 \mathrm{ab}(1.8)$ & $2.00 \mathrm{bc}(0.40)$ & $0.41 \mathrm{ab}(0.23)$ & $486.2 \mathrm{a}(8.8)$ & $11.2 \mathrm{ab}(0.8)$ & $43.7 \mathrm{bc}(2.9)$ & NA \\
\hline Beech-Lime & 18.1ab (1.7) & $1.69 \mathrm{ab}(0.29)$ & $0.47 \mathrm{ab}(0.10)$ & $488.8 \mathrm{a}(8.6)$ & 11.2ab (1.1) & $43.9 \mathrm{bc}(4.0)$ & NA \\
\hline Ash-Lime & $20.0 \mathrm{~b}(2.4)$ & $2.00 \mathrm{bc}(0.32)$ & $0.44 \mathrm{ab}(0.16)$ & $484.5 \mathrm{a}(5.0)$ & $13.2 \mathrm{bc}(1.2)$ & $36.9 \mathrm{ab}(3.3)$ & NA \\
\hline
\end{tabular}

$1.5 \mathrm{mg} \mathrm{g}^{-1}$, respectively; Table 2) and highest in clusters containing ash (19.3 to 20.0 and 2.0 to $2.2 \mathrm{mg} \mathrm{g}^{-1}$, respectively). The concentration of $\mathrm{Mn}$ in litterfall was lowest in ash clusters $\left(0.3 \mathrm{mg} \mathrm{g}^{-1}\right)$ and highest in beech clusters $\left(0.6 \mathrm{mg} \mathrm{g}^{-1}\right)$. It was negatively correlated with the $\mathrm{pH}$ of the topsoil $(0-10 \mathrm{~cm})$ at both subsites (Fig. 2).

\section{Characterization of the forest floor}

The forest floor dry mass (median) in June varied between $0.5 \mathrm{Mg} \mathrm{ha}^{-1}$ under pure ash clusters and 2.2 $\mathrm{Mg} \mathrm{ha}{ }^{-1}$ under beech and beech-lime clusters (Table 3). There was a tendency towards lower forest floor masses in pure ash clusters than in beech and beech-lime clusters $(p<0.1)$.

Stocks of $\mathrm{C}_{\text {org }}$ were higher in pure beech clusters $\left(0.42 \mathrm{Mg} \mathrm{ha}^{-1}\right)$ than in all other variants except beech-lime clusters $\left(0.39 \mathrm{Mg} \mathrm{ha}^{-1}\right)$. The latter differed significantly from pure ash $\left(0.16 \mathrm{Mg} \mathrm{ha}^{-1}\right)$ and ashlime clusters $\left(0.21 \mathrm{Mg} \mathrm{ha}^{-1}\right.$; Table 3$)$. The stock of $\mathrm{N}_{\mathrm{t}}$ in the forest floor was significantly lower in all clusters with ash present than in pure beech and beech-lime clusters and varied from $7.0 \mathrm{~kg} \mathrm{ha}^{-1}$ in pure ash clusters to $16.2 \mathrm{~kg} \mathrm{ha}^{-1}$ in pure beech clusters. The $\mathrm{C}: \mathrm{N}$ ratio of the forest floor did not differ between the two subsites or between variants (Table 3).

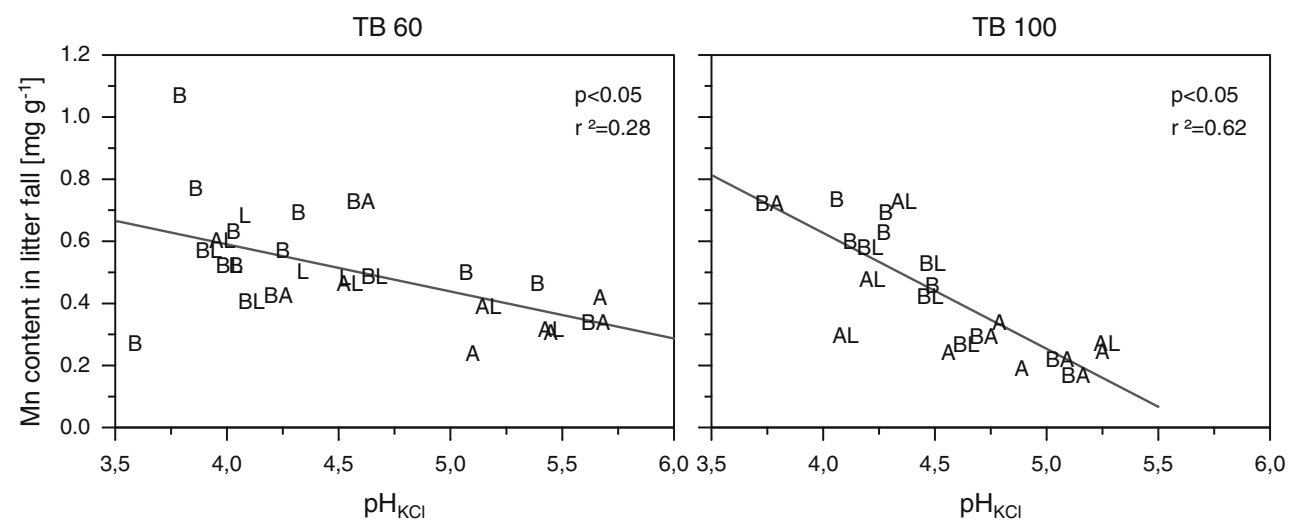

Fig. 2 Relationship between topsoil $\mathrm{pH}(0-10 \mathrm{~cm})$ and $\mathrm{Mn}$ content in litterfall. Pearson correlations are displayed by a linear slope. The cluster variants: A: Ash, B: Beech, L: Lime, BA: Beech-Ash, BL: Beech-Lime, AL: Ash-Lime 


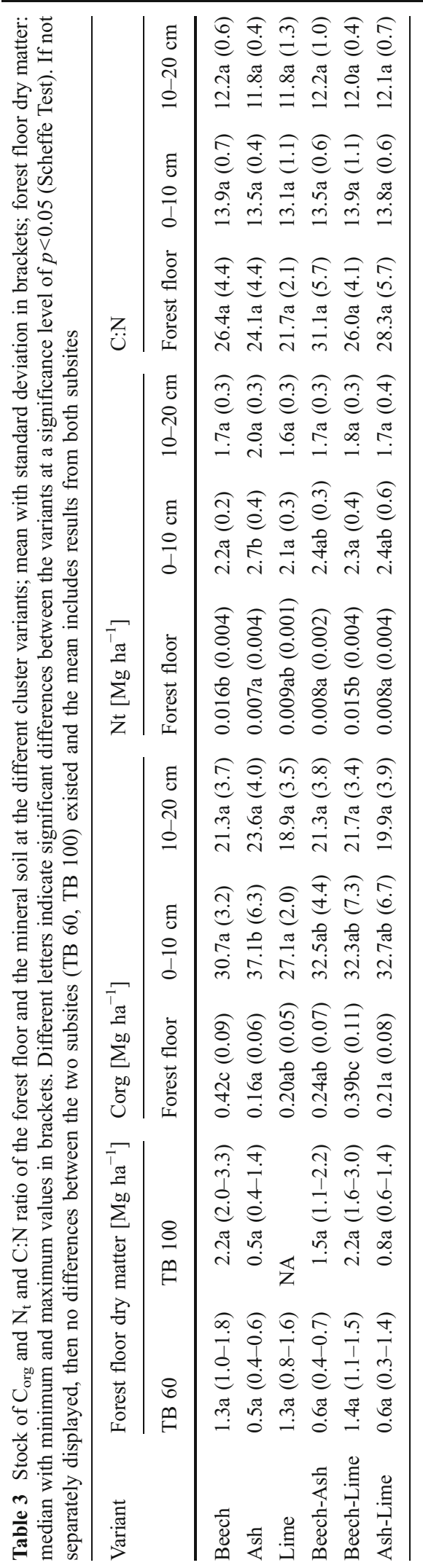

Soil organic carbon and total nitrogen content in the mineral soil

In 0-10 $\mathrm{cm}$ soil depth, the stock of $\mathrm{C}_{\text {org }}$ was significantly higher under pure ash clusters (37.1 $\mathrm{Mg} \mathrm{ha}^{-1}$; Table 3) than under pure beech $\left(30.7 \mathrm{Mg} \mathrm{ha}^{-1}\right)$ and pure lime clusters $\left(27.1 \mathrm{Mg} \mathrm{ha}^{-1}\right)$. The stock of $\mathrm{N}_{\mathrm{t}}$ in the topsoil was significantly higher under pure ash clusters $\left(2.7 \mathrm{Mg} \mathrm{ha}^{-1}\right)$ than under all variants without ash (2.1 to $2.3 \mathrm{Mg} \mathrm{ha}^{-1}$ ). The stocks of $\mathrm{C}_{\text {org }}$ and $\mathrm{N}_{\mathrm{t}}$ did not differ between the variants in 10-20 cm soil depth. The C:N ratio in the mineral soil was similar in all variants (Table 3 ).

Multiple regression analyses revealed that at TB 60, the stocks of $\mathrm{C}_{\text {org }}$ and $\mathrm{N}_{\mathrm{t}}$ were strongly correlated with the clay content in both depths. In addition, in $0-10 \mathrm{~cm} \mathrm{LL}$ ash $/ L_{\text {total }}$ contributed to the variability of $\mathrm{C}_{\text {org }}$ (multiple $\mathrm{R}^{2}=0.59$ ) and $\mathrm{N}_{\mathrm{t}}$ stocks (multiple $\mathrm{R}^{2}=0.72$ ). At TB 100 , where the variability of the clay content was low, $\mathrm{LL}_{\mathrm{ash}} / \mathrm{LL}_{\text {total }}$ was the most important variable explaining the variability of $\mathrm{N}_{\mathrm{t}}$ (multiple $\left.\mathrm{R}^{2}=0.56\right)$ and $\mathrm{C}_{\text {org }}$ stocks $\left(\mathrm{R}^{2}=0.24\right)$ in $0-10 \mathrm{~cm}$ depth. At the depth of 10-20 cm, the clay content was the only variable which correlated with stocks of $\mathrm{C}_{\text {org }}\left(\mathrm{R}^{2}=0.39\right)$ and $\mathrm{N}_{\mathrm{t}}\left(\mathrm{R}^{2}=0.40\right)$.

Soil acidity and exchangeable cations

The soil $\mathrm{pH}$ and base saturation were higher under ash than beech clusters in $0-10 \mathrm{~cm}$ depth. There were no differences in the $\mathrm{pH}$ and base saturation between variants in 10-20 cm depth (Table 4).

The dominant exchangeable cation was $\mathrm{Ca}^{2+}$ which contributed up to $91.5 \%$ in $0-10 \mathrm{~cm}$ and $93.5 \%$ in $10-20 \mathrm{~cm}$ to the CEC, respectively. Neither the proportion of $\mathrm{Ca}^{2+}$ to the CEC nor the stock of exchangeable $\mathrm{Ca}^{2+}$ differed between the variants (Table 4). However, at TB 60, the latter tended to be higher in pure ash clusters than in clusters without ash $(p<0.1)$. The stock of exchangeable $\mathrm{Mg}^{2+}$ in $0-10 \mathrm{~cm}$ depth was higher in ash clusters than in beech clusters at both sites. Further, at TB 60, it was higher in ashlime clusters than in beech clusters. There were no differences between variants in 10-20 cm depth (Table 4).

In $0-10 \mathrm{~cm}$, the percentage of exchangeable $\mathrm{Al}^{3+}$ was lower in pure ash clusters than in beech and beech-lime clusters (the latter only at TB 60, Table 4). Further it also tended to be lower in pure ash clusters 


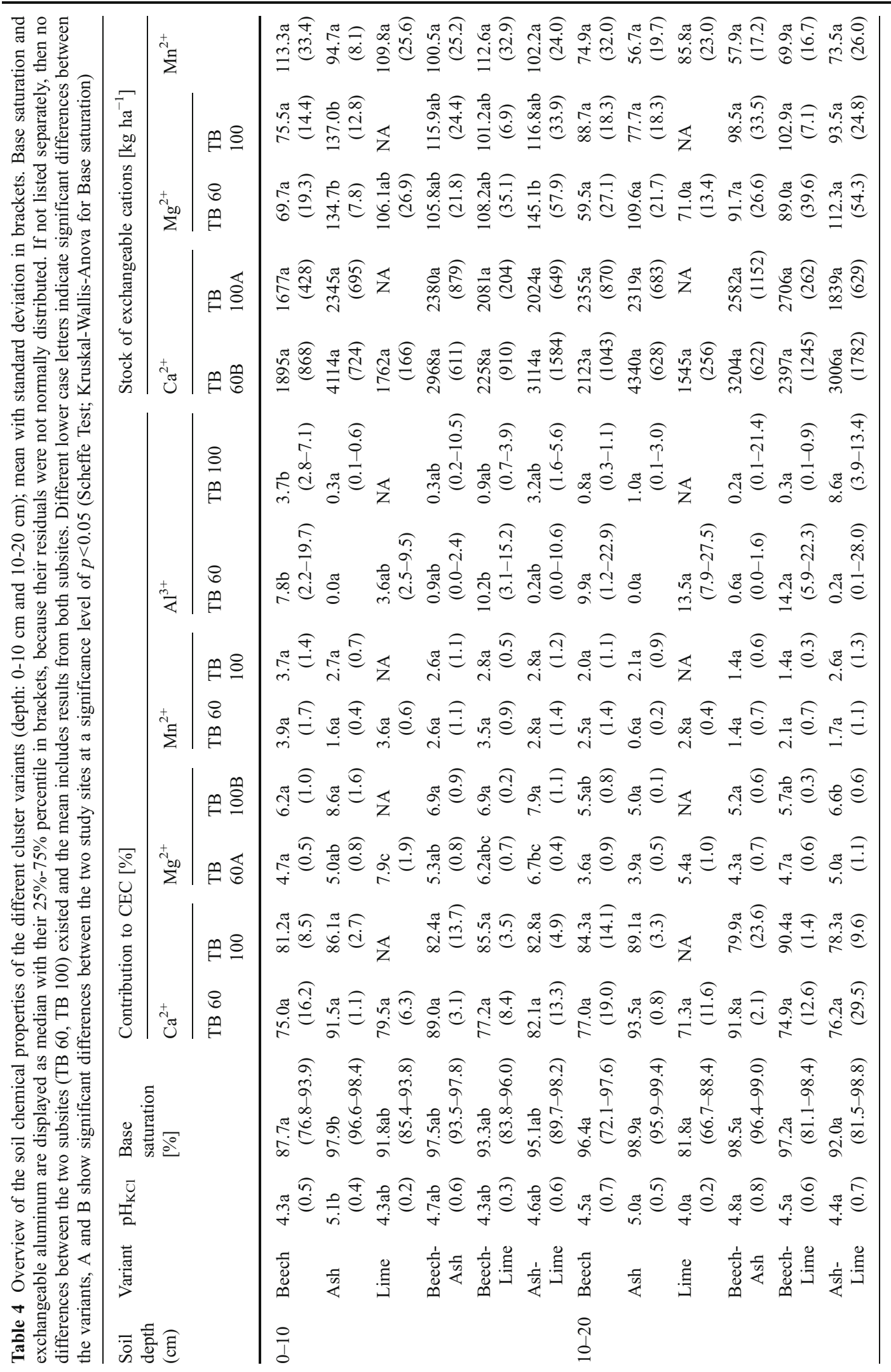


than pure lime clusters $(p<0.1)$. The contribution of $\mathrm{Mn}^{2+}$ to the CEC as well as the stock of exchangeable $\mathrm{Mn}^{2+}$ did not differ between variants in both depths.

At both sites in $0-10 \mathrm{~cm}$ depth, $\mathrm{LL}_{\text {ash }} / \mathrm{LL}_{\text {total }}$ explained a large proportion of the variation of the soil $\mathrm{pH}$. The clay content was the second most important factor which contributed to differences in soil pH (TB 60: multiple $\mathrm{R}^{2}=0.45$, TB 100: multiple $\left.\mathrm{R}^{2}=0.62\right)$. The $\mathrm{pH}$ in $10-20 \mathrm{~cm}$ depth was mainly related to soil clay content $\left(\mathrm{R}^{2}=0.36\right.$ and $\mathrm{R}^{2}=0.41$ at TB 60 and TB 100, respectively).

At TB 60 in $0-10 \mathrm{~cm}$ depth, the clay content explained more than $50 \%$ of the variation in the stocks of exchangeable $\mathrm{Mg}^{2+}$ and $\mathrm{Ca}^{2+}$. In addition, the abundance of beech litterfall reduced the stock of exchangeable $\mathrm{Mg}^{2+}$ (multiple $\mathrm{R}^{2}=0.73$ ) and ash litterfall increased the stock of exchangeable $\mathrm{Ca}^{2+}$ (multiple $\mathrm{R}^{2}=0.64$ ). In contrast to these results, at TB 100 (the site with the more uniform distribution of clay), clay did not influence the stock of exchangeable $\mathrm{Mg}^{2+}$. Here, a simple linear regression with $\mathrm{LL}_{\text {ash }} / \mathrm{LL}_{\text {total }}$ showed the strongest correlation and explained $64 \%$ of the variation of exchangeable $\mathrm{Mg}^{2+}$. Comparably, ash was also the most important variable in multiple regression analysis with the stock of exchangeable $\mathrm{Ca}^{2+}$, which additionally was influenced by the clay content (multiple $\mathrm{R}^{2}=0.52$ ). In general, the stocks of exchangeable $\mathrm{Mg}^{2+}$ and $\mathrm{Ca}^{2+}$ in the mineral soil $(0-10 \mathrm{~cm})$ correlated positively with the input of the respective cation with the litterfall (Fig. 3).

\section{Discussion}

Effects related to the clay content

The results show that, even though clusters were chosen in two small areas (TB 60 and TB 100), the clay content in the upper $20 \mathrm{~cm}$ of the mineral soil varied considerably, in particular at the site with the thinner loess cover (TB 60, Table 1). The clay content did not differ between the cluster variants. However, at TB 60 , the clay content in $10-20 \mathrm{~cm}$ depth tended to be slightly lower in beech clusters than in ash clusters. The uniform distribution of the clay content over the cluster variants, in particular at TB 100, provided a reasonable basis for our analysis of species related effects on small scale differences in soil chemical properties. We have not determined the variability of subsoil clay content and thus we cannot fully exclude that the distribution of ash and lime was influenced by subsoil properties. However, we assume that subsoil effects on species distribution are unlikely at our experimental sites because ash and lime were growing side by side with beech and root systems were overlapping.

Multiple regression analyses revealed that in 10-20 cm depth, the clay content was the dominant variable causing variations in soil acidity and nutrient stocks at both subsites. This is in line with clay contents' general ability to affect CEC and exchangeable base cations (Guckland et al. 2009), soil acidity (Bredemeier et al. 1990) and organic matter storage (Lutzow et al. 2006).

In the upper $10 \mathrm{~cm}$ of the soil, the abundance of ash leaf litterfall and the clay content explained most of the variations in soil acidity and soil nutrient stocks at both subsites. The importance of ash leaf litterfall as an explaining variable increased with decreasing variation in the clay content, and it was the dominant control of small scale variability of soil acidity and nutrient stocks at our subsite TB 100. Covariance analyses revealed comparable results for both subsites concerning differences in soil properties between cluster variants (Table 4), indicating that we successfully disentangled the effect of the clay content and tree species on soil chemical properties.

Fuzziness of approach

Litterfall composition of mono-species clusters revealed that litterfall originated mainly but not exclusively from cluster trees. In particular, beech leaf litterfall from non-cluster trees was found in our litter traps.

The contribution of trees from outside the cluster to litter fall inside the clusters was expected, since it is well known that litter dispersal of different deciduous tree species in mature stands clearly exceeds the distance from our sampling point to the stems of the cluster trees. Results from studies on litter dispersal suggest that most of the leaf litter falls down within a distance of about $18 \mathrm{~m}$ from the stem (Ferrari and Sugita 1996; Rothe 1997; Staelens et al. 2004). However, this distance depends on several factors such as canopy structure, leaf size and wind velocity. Rothe et al. (2002) and Holzwarth et al. (2011) 

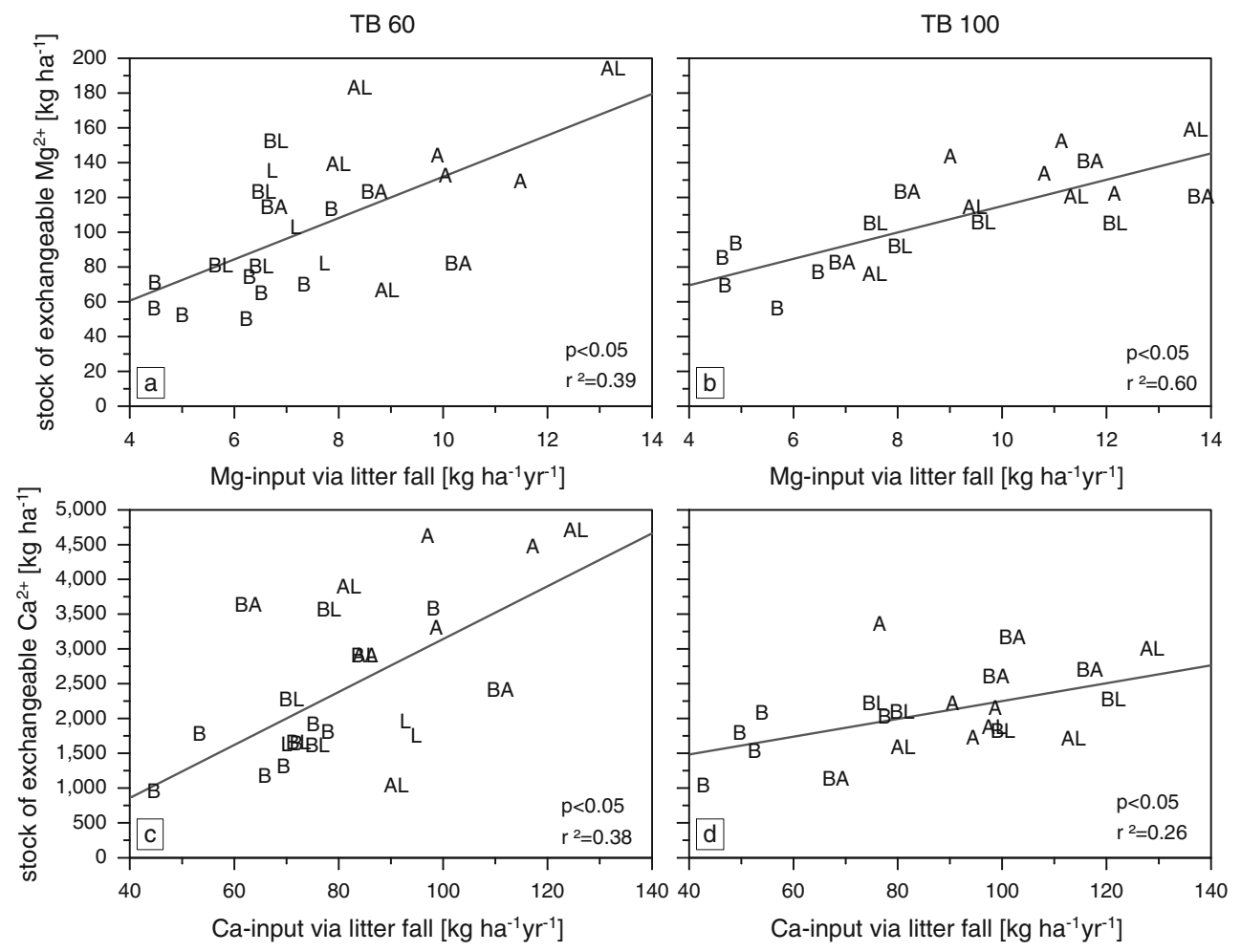

Fig. 3 Influence of $\mathrm{Mg}$ input $\mathbf{a}, \mathbf{b}$ and $\mathrm{Ca}$ input $\mathrm{c}, \mathrm{d}$ via litter fall on the stock of the respective exchangeable cation in 0-10 cm depth at TB 60 and TB 100. Significant linear

pointed out that soil samples of a given point in a mature deciduous forest are influenced by the tree species within a radius of about $10 \mathrm{~m}$. Thus our results do not reflect conditions in mono-species stands, larger groups of single tree species or well defined mixtures of different species, but rather represent natural conditions in a highly diverse deciduous mixed forest. This implies the fuzziness of a heterogeneous mixture of different tree species, which reduces possible effects of tree species on soil properties

\section{Effects related to leaf litter composition}

Our results show that the distribution of ash induced small scale variations in soil chemical properties, such as soil acidity or nutrient stocks, in a beechdominated temperate mixed broadleaved forest. The influence of ash was most pronounced in the forest floor and in the topsoil $(0-10 \mathrm{~cm})$ and could be related to leaf litter composition. Nordén (1994) discovered partly contracting effects of tree species on base correlations (Pearson; $p<0.05$ ) are displayed by a linear slope. The cluster variants: A: Ash, B: Beech, L: Lime, BA: BeechAsh, BL: Beech-Lime, AL: Ash-Lime

saturation in the topsoil compared to deeper horizons and reasoned that in the topsoil, leaf litterfall is the dominant control on soil acidity (higher $\mathrm{pH}$ value under lime trees than under beech or oak). Hansen et al. (2009) figured that the accumulation of $\mathrm{C}$ and nutrients in the forest floor are basically controlled by decomposition of litterfall. Our results agree with the general observations that effects of tree species on soil chemical properties appear mainly in the topsoil (Augusto et al. 2003; Hagen-Thorn et al. 2004; Guckland et al. 2009; Mareschal et al. 2010).

\section{Nutrient contents in litterfall}

We found clear species-specific differences in leaf litter composition of trees growing at the same site (Table 2). Such differences are considered to be intrinsic species-specific traits. In line with our results, several studies found lower quantities of base cations but a higher $\mathrm{Mn}$ content (in comparison to only ash litter) and a higher $\mathrm{C}: \mathrm{N}$ ratio and lignin: $\mathrm{N}$ ratio in beech litterfall compared to ash and lime 
litterfall (Reich et al. 2005; Vesterdal et al. 2008; Jacob et al. 2009; Jacob et al. 2010). Besides the tree species itself, other factors like tree age (Vesterdal et al. 2008), soil fertility status (Sariyildiz and Anderson 2005) or annual variations (Jacob et al. 2009) may cause variations in litterfall chemistry of a single species. Meier et al. (2005), who analyzed nutrient returns with litterfall in beech forests found intermediate variations in $\mathrm{Ca}$ and $\mathrm{Mg}$ return and large variations in $\mathrm{Al}$ and $\mathrm{Mn}$ return with litterfall across a soil fertility gradient. There was no evidence in our study that the observed small scale variation of the topsoil chemistry affected litter composition.

The horizontal and vertical expansion of nutrient uptake by the root system is generally much larger than the observed differences in soil chemistry which are restricted to the upper $10 \mathrm{~cm}$ of the soil (Leuschner et al. 2004). For the Hainich National Park, Meinen et al. (2009a) found that 63 to $77 \%$ of fine roots are concentrated in the upper $20 \mathrm{~cm}$ of mineral soil, but there were still fine roots in depths larger than $40 \mathrm{~cm}$ of mineral soil. However, root activity may differ from fine root biomass distribution and can be very variable and allows subsoil resource use (Lehmann 2003).

\section{Organic carbon and total nitrogen in mineral soil and forest floor}

We found higher stocks of $\mathrm{C}_{\text {org }}$ and $\mathrm{N}_{\mathrm{t}}$ in the forest floor under beech than under ash, but stocks of $\mathrm{C}_{\text {org }}$ and $\mathrm{N}_{\mathrm{t}}$ in the mineral soil $(0-10 \mathrm{~cm})$ were smaller under beech and lime than under ash (Table 3 ). The results point at a faster turnover rate of ash litterfall compared to beech litterfall resulting in a faster, more efficient nutrient return to the soil (Oostra et al. 2006; Vesterdal et al. 2008; Jacob et al. 2009). Carbon accumulation in the forest floor depends on several interacting factors: The most important are litter quality (i. e. the lignin content and the lignin: $\mathrm{N}$ ratio, compare Berg 2000; Inagaki et al. 2004), soil fertility and activity of soil biota. The higher lignin and lower $\mathrm{N}$ content resulting in a higher lignin: $\mathrm{N}$ ratio of beech leaf litterfall, compared with ash and lime, results in a generally higher recalcitrance and slower rate of decomposition (Melillo et al. 1982; Finzi et al. 1998; Jacob et al. 2010). Our results are in line with the conclusion of Guckland et al. (2009), Vesterdal et al. (2008) and Kooijman and Cammeraat (2010) that
$\mathrm{C}$ accumulation in the forest floor of deciduous tree stands is largely determined by the abundance of beech litterfall. Vesterdal et al. (2008) observed that forest floor $\mathrm{C}_{\text {org }}$ and $\mathrm{N}_{\mathrm{t}}$ stocks were related to $\mathrm{C}: \mathrm{N}$ ratio of litterfall, which agrees with the findings in our study. Leuschner et al. (2006) analyzed the soil nutrient status in 50 European beech stands. They found that the stock of $\mathrm{N}$ in the forest floor was closely related to the content of exchangeable $\mathrm{Al}^{3+}$ in the mineral soil, indicating that elevated $\mathrm{Al}^{3+}$ contents negatively influence the activity of soil organisms due to Al toxicity and reduce decomposition and incorporation of organic matter into the mineral soil by bioturbation. This might additionally explain differences in stocks of $\mathrm{N}$ between our cluster variants because we found highest contents of exchangeable $\mathrm{Al}^{3+}$ in the soils of pure beech clusters (Table 4). The $\mathrm{C}: \mathrm{N}$ ratio of the organic layer did not reflect the higher $\mathrm{N}$ content of ash and lime leaf litterfall compared to beech (compare Tables 2 and 3). We assume that this is a result of the sampling time in June, because ash and lime litterfall was already decomposed at this time and the sampled forest floor consisted mainly of beech litterfall.

\section{Tree species effect on soil acidity and exchangeable} cations

The mixture of different broadleaved tree species resulted in a spatial variability of topsoil chemistry (e.g. soil acidity, exchangeable base cations). Our results show that this variability was largely determined by the abundance of ash leaf litterfall, which had highest contents of $\mathrm{Mg}$ and $\mathrm{Ca}$.

Our results agree with the conclusion of Neirynck et al. (2000) that the surface soil nutrient status is influenced by the ability of different tree species to improve or maintain soil productivity via nutrient uptake and redistribution. Augusto et al. (2002) summarized effects of tree species on soil fertility and concluded that the acidifying effect of beech and oak on soil $\mathrm{pH}$ was higher than for all other deciduous trees. The ability of tree species to reduce acidification and increase the nutrient availability in topsoils was mainly related to the $\mathrm{Ca}$ and $\mathrm{Mg}$ concentration in litterfall and the litter ash alkalinity (Noble and Randall 1999; Dijkstra 2003; Reich et al. 2005).

Our results confirm the assumption of Guckland et al. (2009) of having detected a beech gradient effect 
on soil acidity and nutrient contents in Hainich National Park. However, the abundance of ash showed an even more profound influence on soil acidity than the abundance of beech. Our results indicate that the addition of ash leaf litter in beech dominated stands on loess over limestone reduced soil acidification and led to higher stocks of exchangeable macro nutrients such as $\mathrm{Mg}^{2+}$ or $\mathrm{Ca}^{2+}$. A positive effect of ash on topsoil fertility was also observed in other studies (Neirynck et al. 2000; Hagen-Thorn et al. 2004; Oostra et al. 2006). In some cases it was difficult to separate effects of tree species from effects induced by heterogeneity of the soil texture (Alriksson and Eriksson 1998; Guckland et al. 2009) or soil parent material (Augusto et al. 1998). We were able to separate these effects at least at TB 100 (i. e. effects of clay content and tree species) and the results show that the abundance of ash leaf litterfall significantly contributed to the variability in soil acidity and stocks of exchangeable base cations. This effect was restricted to the top $10 \mathrm{~cm}$ of mineral soil. The effect of tree species on the redistribution of $\mathrm{Ca}$ and $\mathrm{Mg}$ in the soil profile through nutrient uptake and litterfall and mineralization depend on soil properties such as the nutrient availability and buffer capacity at different soil depths (Noble and Randall 1999; Augusto et al. 2002; Meier et al. 2005). In our clusters, the biological pumping of base cations from the subsoil was of great importance, because loess has a rather low buffer capacity and thus tends to form strongly acid forest soils (Guckland et al. 2009). Guckland et al. (2009) supposed that the ameliorating effects through nutrient uptake from the deep soil layers, litterfall and mineralization differed between species and counteracted the accumulation of acid cations at the exchange complex. Thus, the replacement of exchangeable base cations was minimized (Guckland et al. 2009). The vertical extension of tree species effects on soil properties probably depends on soil texture and the related $\mathrm{pH}$ buffer capacity and CEC of soils e.g. Nordén (1994) found species related effects on soil acidity and exchangeable cations down to a depth of $70 \mathrm{~cm}$ on a sandy site with 2 to $3 \%$ clay.

We found no clear effect of lime on soil acidity and stocks of exchangeable nutrients (Table 4). In contrast, several studies detected higher $\mathrm{pH}$ values, base saturation and nutrient stocks in soils under lime than under beech (Nordén 1994; Neirynck et al. 2000; Hagen-Thorn et al. 2004). Neirynck et al. (2000) and
Hagen-Thorn et al. (2004) compared soil properties of adjacent plots of monospecific stands and therefore did not have any litter mixture of different tree species. In our study (i.e. tree species standing in mixture in a mature forest), the mixture of different litter types led to blurs, which are usual in natural conditions. We assume, that the effect of lime on soil properties might have been more pronounced in larger groups of lime, where the admixture of beech litterfall is smaller. However, additional studies are required to be able to capture and quantify the influence of tree species distribution on the variability of soil properties in different locations and, in a further step, to distinguish between general and site-specific species-induced influences on soil properties.

The Mn content in litterfall correlated negatively with the $\mathrm{pH}$ in the upper mineral soil at both subsites. This can be explained by the dissolution of Mn oxides with decreasing $\mathrm{pH}$, which results in a greater bioavailability of Mn (Schachtschabel 1957). Our results suggest that the higher Mn content in beech leaf litter than ash leaf litter was influenced by the stronger soil acidification under beech.

Overall, our results indicate that in a diverse stand the abundance and distribution of individual tree species accounted for the variation in soil chemical properties and the sum of these species make up the soil chemical properties of the whole forest stand. Jacob et al. (2009) came to the same conclusion concerning litter decomposition rates. Guckland et al. (2009) also suggested that they rather detected a beech gradient than a biodiversity effect as a cause of decreasing soil acidification and an increase of base cations in more diverse stands (one-species stands were all of beech).

Besides the influence of leaf litter quality on soil properties, tree species can alter soil properties through various factors. Among the most important are the capacity of tree species to intercept atmospheric deposition (Augusto et al. 2002; Talkner et al. 2010), variations in the amount and distribution of throughfall (Augusto et al. 2002; Barbier et al. 2009), stemflow (Falkengren-Grerup 1989; Koch and Matzner 1993), root growth (Lehmann 2003; Meinen et al. 2009) and spatial and temporal differences in water and nutrient uptake (Augusto et al. 2002; Bittner et al. 2010). Stemflow of different tree species in the Hainich National Park was analyzed by Krämer and Hölscher (2009) and Talkner et al. (2010). It was 
$2-6 \%$ of total precipitation (while throughfall was between 66 and $77 \%$ of total precipitation) and it was lower for ash and lime than for beech (Krämer and Hölscher 2009). The results support the observation that stemflow of beech increases soil acidification near the trunk (Falkengren-Grerup 1989; Koch and Matzner 1993). Since this acidifying effect is restricted to a small distance from the trunk $(<1.5$ to $2 \mathrm{~m}$; Falkengren-Grerup 1989) it cannot explain the different soil acidity in the center of our tree clusters. Talkner et al. (2010) found that deposition of $\mathrm{Ca}$ and $\mathrm{Mg}$ via throughfall was lower and acid deposition was higher in pure beech stands than in mixed species stands in the Hainich National Park. This observation was explained by canopy processes which resulted in different canopy leaching rates of $\mathrm{Ca}$ and $\mathrm{Mg}$. The results suggest that differences in canopy exchange processes and deposition between the studied tree species might additionally have influenced differences of soil chemical properties in our tree clusters.

Root distribution, composition of root litter and rhizosphere properties are further factors which may cause species specific effects on soil properties (Hinsinger et al. 2005; Calvaruso et al. 2011). Meinen et al. (2009a, 2009b) determined total root biomass and root distribution of different tree species close to our cluster sites. They found no evidence of spatial root system segregation or elevated root biomass in multi-species sites. Fine root biomass of a single tree within the distance of 2 to $5 \mathrm{~m}$ (cluster radius) from the stem was approximately 400 to $600 \mathrm{gm}^{-2}(0-40 \mathrm{~cm}$ depths) and did not differ between species. Meinen et al. (2009b) found a high degree of root system overlap in mixed stands. The change of fine root biomass with increasing stem distance suggest that fine roots in our soil samples originated mainly from the three cluster trees. Lang (2008) found that $\mathrm{N}$ and $\mathrm{Mg}$ contents of tree fine roots in the Hainich National Park were higher for ash than beech. These differences of root composition might have contributed to the observed effects of ash on soil chemical properties.

\section{Conclusion}

Our results show that the presence of ash in a speciesrich (although beech dominated) temperate forest on a luvisol of loess over limestone reduced soil acidification and enlarged the stocks of exchangeable base cations, organic carbon and total nitrogen in the topsoil $(0-10 \mathrm{~cm})$. The results on litterfall quality and distribution indicate that these changes of topsoil properties were caused, to a large extent, by differences in leaf litterfall chemistry. The distribution of ash resulted not only in above-ground diversity of stand structure but also caused distinct small scale belowground diversification of the soil habitat. The results from the different tree clusters show that small scale variability of soil chemical properties was not only driven by species mixture and identity but also by the spatial distribution of individual species (e. g. grouping of ash increases the range of variation of chemical soil properties). Thus, ash leaf litter not only reduced soil acidity and increased nutrient availability but also led to an increased diversity of the soil habitat in beech stands. The soil clay content was the primary factor which explained spatial variability of soil acidity, soil organic carbon content, and exchangeable base cations. The influence of ash on chemical topsoil properties was only dominant in stands with low variability of soil clay content. We found no influence of clay content or cluster species on the composition of beech, ash and lime leaf litter.

Acknowledgement The study was funded by the Deutsche Forschungsgemeinschaft (DFG; Graduate School 1086). We are grateful to the National Park administration for the permission to conduct the study in Hainich National Park. We thank our colleagues of the graduate school 1086 for technical assistance and N. Legner for helpful discussions. Further, we thank Prof. Dr. Saborowski for being a helping hand concerning statistical questions. Thanks to J. Gordon for proof-reading the English spelling and grammar. We thank Dr. A. Guckland for her internal review of the manuscript concerning its intelligibility, plausibility and consistency. We thank two anonymous reviewers for their valuable comments on the manuscript and the working group of Prof. Dr. Polle for conducting the measurements of the Lignin content.

Open Access This article is distributed under the terms of the Creative Commons Attribution Noncommercial License which permits any noncommercial use, distribution, and reproduction in any medium, provided the original author(s) and source are credited.

\section{References}

Alriksson A, Eriksson HM (1998) Variations in mineral nutrient and $\mathrm{C}$ distribution in the soil and vegetation compartments of five temperate tree species in NE Sweden. For Ecol Manage 108:261-273 
Augusto L, Bonnaud P, Ranger J (1998) Impact of tree species on forest soil acidification. For Ecol Manage 105:67-78

Augusto L, Ranger J, Binkley D, Rothe A (2002) Impact of several common tree species of European temperate forests on soil fertility. Ann For Sci 59:233-253

Augusto L, Dupouey JL, Ranger J (2003) Effects of tree species on understory vegetation and environmental conditions in temperate forests. Ann For Sci 60:823-831

Barbier S, Balandier P, Gosselin F (2009) Influence of several tree traits on rainfall partitioning in temperate and boreal forests: a review. Ann For Sci 66:602

Berg B (2000) Litter decomposition and organic matter turnover in northern forest soils. For Ecol Manage 133:13-22

Berger TW, Inselsbacher E, Mutsch F, Pfeffer M (2009a) Nutrient cycling and soil leaching in eighteen pure and mixed stands of beech (Fagus sylvatica) and spruce (Picea abies). For Ecol Manage 258:2578-2592

Berger TW, Untersteiner H, Toplitzer M, Neubauer C (2009b) Nutrient fluxes in pure and mixed stands of spruce (Picea abies) and beech (Fagus sylvatica). Plant Soil 322:317342

Binkley D, Giardina C (1998) Why do tree species affect soils? The warp and woof of tree-soil interactions. Biogeochemistry 42:89-106

Bittner S, Talkner U, Krämer I et al (2010) Modeling stand water budgets of mixed temperate broad-leaved forest stands by considering variations in species specific drought response. Agr Forest Meteorol 150:1347-1357

Bredemeier M, Matzner E, Ulrich B (1990) Internal and external proton lead to forest soils in Northern Germany. J Environ Qual 19:469-477

Brinkmann K, Blaschke L, Polle A (2002) Comparison of different methods for lignin determination as a basis for calibration of near-infrared reflectance spectroscopy and implications of lignoproteins. J Chem Ecol 28:2483-2501

Calvaruso C, N'Dira V, Turpault MP (2011) Impact of common European tree species and Douglas-fir (Pseudotsuga menziesii [Mirb.] Franco) on the physiochemical properties of the rhizosphere. Plant Soil 342:469-480

Dijkstra FA (2003) Calcium mineralization in the forest floor and surface soil beneath different tree species in the northeastern US. For Ecol Manage 175:185-194

Falkengren-Grerup U (1989) Effect of stemflow on beech forest soils and vegetation in southern Sweden. J Appl Ecol 26:341-352

Ferrari JB, Sugita S (1996) A spatially explicit model of leaf litter fall in hemlock-hardwood forests. Can J For Res 26:1905-1913

Finzi AC, Breemen NV, Canham CD (1998) Canopy tree-soil interactions within temperate forests: species effects on soil carbon and nitrogen. Ecol Appl 8:440-446

Guckland A, Jacob M, Flessa H, Thomas FM, Leuschner C (2009) Acidity, nutrient stocks, and organic-matter content in soils of a temperate deciduous forest with different abundance of European beech (Fagus sylvatica L.). J Plant Nutr Soil Sci 172:500-511

Hagen-Thorn A, Callesen I, Armolaitis N (2004) The impact of six European tree species on the chemistry of mineral topsoil in forest plantations on former agricultural land. For Ecol Manage 195:373-384
Hansen K, Vesterdal L, Schmidt IK et al (2009) Litterfall and nutrient return in five tree species in a common garden experiment. For Ecol Manage 257:2133-2144

Heinrichs, Brumsack, Loftfield, König (1986) Verbessertes Druckaufschlußsystem für biologische und anorganische Materialien. Z Pflanzenern Bodenk 149:350-353

Hinsinger P, Gobran G, Gregory PJ, Wenzel WW (2005) Rhizosphere geometry and heterogeneity arising from root-mediated physical and chemical processes. New Phytol 168:293-303

Holzwarth, Guckland, Flessa (2011) Effects of beech and ash on small scale variation of soil acidity and nutrient stocks in a mixed deciduous forest. J Plant Nutr Soil Sci

Inagaki Y, Miura S, Kohzu A (2004) Effects of forest type and stand age on litterfall quality and soil $\mathrm{N}$ dynamics in Shikohu district, southern Japan. For Ecol Manage 202:107-117

Jacob M, Weland N, Platner C et al (2009) Nutrient release from decomposing leaf litter of temperate deciduous forest trees along a gradient of increasing tree species diversity. Soil Biol Biochem 41:2122-2130

Jacob M, Viedenz K, Polle A, Thomas FM (2010) Leaf litter decomposition in temperate deciduous forest stands with a decreasing fraction of beech (Fagus sylvatica). Oecologia 164:1083-1094

Koch AS, Matzner E (1993) Heterogeneity of soil and soil solution chemistry under Norway spruce (Picea abies Kart.) and European beech (Fagus sylvatica L.) as influenced by distance from the stem basis. Plant Soil 151:227-237

König F (1996) Probenvorbereitungs-, Untersuchungs- und Elementbestimmungs-Methoden des UmweltanalytikLabors der Niedersächsischen Forstlichen Versuchsanstalt und des Zentrallabors II des Forschungszentrums Waldökosysteme. Teil 3: Gerätekurzanleitungen und Gerätekurzanleitungen Datenverarbeitung. Berichte des Forschungszentrums Waldökosysteme der Universität Göttingen, B 48

Kooijman AM, Cammeraat E (2010) Biological control of beech and hornbeam affects species richness via changes in the organic layer, $\mathrm{pH}$ and soil moisture characteristics. Funct Ecol 24:469-477

Krämer I, Hölscher D (2009) Rainfall partitioning along a tree diversity gradient in a deciduous old-growth forest in Central Germany. Ecohydrol 2:102-114

Lang C (2008) Diversität der Ektomykorrhizen in verschieden artenreichen Laubbaumbeständen im Nationalpark Hainich (Thüringen). Göttinger Forstwissenschaften 1. Dissertation, Georg August Universität Göttingen

Lehmann J (2003) Subsoil root activity in tree-based cropping systems. Plant Soil 255:319-331

Leuschner C, Hertel D, Schmid I et al (2004) Stand fine root biomass and fine root morphology in old-growth beech forests as a function of precipitation and soil fertility. Plant Soil 258:43-56

Leuschner C, Meier IC, Hertel D (2006) On the niche breadth of Fagus sylvatica: soil nutrient status in 50 Central European beech stands on a broad range of bedrock types. Ann For Sci 63:14

Lutzow Mv, Kogel-Knabner I, Ekschmitt K et al (2006) Stabilization of organic matter in temperate soils: mechanisms and their relevance under different soil conditionsa review. Eur J Soil Science 57:426-445 
Mareschal L, Bonnaud P, Turpault MP, Ranger J (2010) Impact of common European tree species on the chemical and physicochemical properties of fine earth: an unusual pattern. Eur J Soil Sci 61:14-23

Meier IC, Leuschner C, Hertel D (2005) Nutrient return with leaf litter fall in Fagus sylvatica forests across a soil fertility gradient. Plant Ecol 177:99-112

Meinen C, Hertel D, Leuschner C (2009a) Biomass and morphology of fine roots in temperate broad-leaved forests differing in tree species diversity: is there evidence of below-ground overyielding? Oecologia 161:99-111

Meinen C, Leuschner C, Ryan NT, Hertel D (2009b) No evidence of spatial root system segregation and elevated fine root biomass in multi species temperate broad-leaved forests. Trees 23:941-950

Melillo JM, Aber JD, Muratore JF (1982) Nitrogen and lignin control of hardwood leaf litter decomposition dynamics. Ecology 63:621-626

Mölder A, Bernhardt-Römermann M, Schmidt W (2006) Forest ecosystem research in Hainich National Park (Thuringia): first results on flora and vegetation in stands with contrasting tree species diversity. Waldoekologie online 3:83-99

Morrison IM (1972) A semi-micro method for the determination of lignin and its use in predicting the digestibility of forage crops. J Sci Fd Agric 23:455-463

Neirynck J, Mirtcheva S, Sioen G, Lust N (2000) Impact of Tilia platyphyllos Scop., Fraxinus excelsior L., Acer pseudoplatanus L., Quercus robur L. and Fagus sylvatica L. on earthworm biomass and physico-chemical properties of a loamy topsoil. For Ecol Manage 133:275-286

Noble A, Randall P (1999) Alkalinity effects of different tree litters incubated in an acid soil of NSW, Australia. Agrofor Syst 46:147-160

Nordén U (1994) Influence of tree species on acidification and mineral pools in deciduous forest soils of South Sweden. Water Air Soil Pollut 76:363-381

Oostra S, Majdi H, Olsson M (2006) Impact of tree species on soil carbon stocks and soil acidity in southern Sweden. Scand J For Res 21:364-371
Reich PB, Oleksyn J, Modrzynski J et al (2005) Linking litter calcium, earthworms and soil properties: a common garden test with 14 tree species. Ecol Lett 8:811-818

Rothe A (1997) Einfluß des Baumartenanteils auf Durchwurzelung, Wasserhaushalt, Stoffhaushalt und Zuwachsleistung eines Fichten-Buchen-Mischbestandes am Standort Höglwald, Forstliche Forschungsberichte München

Rothe A, Binkley D (2001) Nutritional interactions in mixed species forests: a synthesis. Can J For Res 31:1855-1870

Rothe A, Kreutzer K, Küchenhoff H (2002) Influence of tree species composition on soil and soil solution properties in two mixed spruce-beech stands with contrasting history in Southern Germany. Plant Soil 240:47-56

Sariyildiz T, Anderson J (2005) Variation in the chemical composition of green leaves and leaf litters from three deciduous tree species growing on different soil types. For Ecol Manage 210:303-319

Schachtschabel P (1957) Die Bestimmung des Manganversorgungsgrades von Böden und seine Beziehung zum Auftreten der Dörrfleckenkrankheit bei Hafer. Z Pflanz, Düngung, Bodenkunde 78:147-167

Schlichting E, Blume H-P, Stahr K (1995) Bodenkundliches Praktikum: eine Einführung in pedologisches Arbeiten für Ökologen, insbesondere Land- und Forstwirte und für Geowissenschaftler, 2nd edn. Blackwell WissenschaftsVerlag, Berlin

Staelens J, Nachtergale L, Luyssaert S (2004) Predicting the spacial distribution of leaf litterfall in a mixed deciduous forest. For Sci 50:836-847

Talkner U, Krämer I, Hölscher D, Beese FO (2010) Deposition and canopy exchange processes in central-German beech forests differing in tree species diversity. Plant Soil 336:405-420

Vesterdal L, Schmidt I, Callesen I, Nilsson L, Gundersen P (2008) Carbon and nitrogen in forest floor and mineral soil under six common European tree species. For Ecol Manage 255:35-48

Zanella A, Jabiol B, Ponge J-F et al (2011) European humus forms reference base. http://hal.archives-ouvertes.fr/hal00541496/. Accessed 1 April 2011 